\title{
Conjugation of ampicillin and enrofloxacin residues with bovine serum albumin and raising of polyclonal antibodies against them
}

\author{
B. Sampath Kumar, Vasili Ashok, P. Kalyani and G. Remya Nair \\ Department of Veterinary Biochemistry, College of Veterinary Science, Sri Venkateswara Veterinary University, Korutla, \\ Karimnagar, Telangana, Andhra Pradesh, India. \\ Corresponding author: B. Sampath Kumar, e-mail: samkum85@gmail.com, \\ VA: vasiliashok@gmail.com, PK: parvathalakalyani@gmail.com, GRN: remyagnair10@gmail.com \\ Received: 29-07-2015, Accepted: 14-03-2016, Published: 26-04-2016
}

doi: 10.14202/vetworld.2016.410-416 How to cite this article: Kumar BS, Ashok V, Kalyani P, Nair GR (2016) Conjugation of ampicillin and enrofloxacin residues with bovine serum albumin and raising of polyclonal antibodies against them, Veterinary World, 9(4): 410-416.

\begin{abstract}
Aim: The aim of this study is to test the potency of bovine serum albumin (BSA) conjugated ampicillin (AMP) and enrofloxacin (ENR) antigens in eliciting an immune response in rats using indirect competitive enzyme-linked immunosorbent assay (icELISA).

Materials and Methods: AMP and ENR antibiotics were conjugated with BSA by carbodiimide reaction using 1-ethyl3-(3-dimethylaminopropyl) carbodiimide (EDC) as a cross-linker. The successful conjugation was confirmed by sodium dodecyl sulfate polyacrylamide gel electrophoresis. Sprague-Dawley rats were immunized with the conjugates and blood samples were collected serially at 15 days time interval after first immunization plus first booster, second booster, third booster, and the fourth sampling was done $1 \frac{1}{2}$ month after the third booster. The antibody titres in the antisera of each antibiotic in all the four immunization cycles (ICs) were determined by an icELISA at various serum dilutions ranging from $1 / 100$ to $1 / 6400$.

Results: Analysis of antibiotic-BSA conjugates by sodium dodecyl sulfate polyacrylamide gel electrophoresis and coomassie blue staining revealed high molecular weight bands of $85 \mathrm{kDa}$ and $74 \mathrm{kDa}$ for AMP-BSA and ENR-BSA respectively when compared to $68 \mathrm{kDa}$ band of BSA. Both the antibiotic conjugates elicited a good immune response in rats but comparatively the response was more with AMP-BSA conjugate than ENR-BSA conjugate. Maximum optical density 450 value of 2.577 was recorded for AMP-BSA antisera, and 1.723 was recorded for ENR-BSA antisera at $1 / 100^{\text {th }}$ antiserum dilution in third IC.

Conclusion: AMP and ENR antibiotics proved to be good immunogens when conjugated to BSA by carbodiimide reaction with EDC as crosslinker. The polyclonal antibodies produced can be employed for detecting AMP and ENR residues in milk and urine samples.
\end{abstract}

Keywords: 1-ethyl-3-(3-dimethylaminopropyl) carbodiimide, antibodies against antibiotics, conjugation, indirect competitive enzyme linked immunosorbent assay.

\section{Introduction}

Antibiotics are being used extensively in the treatment of sick animals. They are also being used as growth promoters and prophylactic agents in lactating animals which is responsible for the presence of their residues in the milk [1]. Beta-lactam antibiotics like penicillin are the most frequently used, the residues of which can produce detrimental effects such as allergic reactions in humans who are sensitive to beta-lactams [2]. It may also lead to the development of antibiotic-resistant strains of bacteria [3]. Antibiotics when used inappropriately and irrationally it provides favorable conditions for the development of a resistant group of microbes that can

Copyright: Kumar, et al. Open Access. This article is distributed under the terms of the Creative Commons Attribution 4.0 International License (http://creativecommons.org/licenses/by/4.0/), which permits unrestricted use, distribution, and reproduction in any medium, provided you give appropriate credit to the original author(s) and the source, provide a link to the Creative Commons license, and indicate if changes were made. The Creative Commons Public Domain Dedication waiver (http://creativecommons.org/ publicdomain/zero/1.0/) applies to the data made available in this article, unless otherwise stated. spread very easily [4]. Enrofloxacin (ENR) is widely used in the treatment of infectious diseases because of its broad spectrum activity, and this may result in persistence of ENR residues in animal body which in turn might lead to the development of drug-resistant bacterial strains or allergies in the animal [5]. Dinki and Balcha [6] reported antibiotic residues in 28 samples with $23.3 \%$ detection rate in cattle milk samples collected from six different milk collection centres in Guwahati city in India. Gentamycin and streptomycin residues were estimated to be $90 \mu \mathrm{g} / \mathrm{L}$ and $80 \mu \mathrm{g} / \mathrm{L}$ respectively by Zeina et al. [7]. in cattle milk in Lebanon which were below the maximum residue limit of $200 \mu \mathrm{g} / \mathrm{L}$ set by FAO/WHO. A study conducted in Nepal by Dhakal et al. [8] revealed that mastitis pathogens have developed resistance to ampicillin (AMP) and penicillin. Gentamycin and streptomycin are found to be developing resistance. All these results emphasize the need to have strict control measures on the use of antibiotics in veterinary practice both as therapeutic as well as prophylactic agents and also the need to have rapid 
and sensitive screening methods to detect antibiotic residues in milk.

Antibiotics are small molecules with molecular weights of $<1 \mathrm{kDa}$ (haptens) and to elicit an immune response, they have to be conjugated with carrier molecules such as bovine serum albumin (BSA) [9].

Antibodies are utilized for analysis, purification, and enrichment, and to mediate or modulate physiological responses. The ability of antibodies to bind an antigen with a high degree of affinity and specificity has led to their ubiquitous use in a variety of scientific and medical disciplines. Their use in diagnostic assays and as therapeutics has had a profound impact on the improvement of health and welfare in both humans and animals [10].

This study was undertaken with the objective of producing polyclonal antibodies (pAbs) against AMP and ENR antibiotics by conjugating them with BSA and detection of these pAbs by a sensitive indirect competitive enzyme linked immunosorbent assay (icELISA) in antibiotic specific antisera.

\section{Materials and Methods \\ Ethical approval}

The experimental protocol was approved by the Institutional Animal Ethics Committee under order No. $8 / \mathrm{i} / 10$.

\section{Animals}

The rats (Sprague-Dawley) for the experiment were procured from the National Institute of Nutrition, Hyderabad (No. DBT/LAISC 2455). The Sprague-Dawley rats aged 7-8 weeks were kept under well lighted experimental house and maintained on standard rat feed with ad libitum water. A total three groups with three rats in each were maintained, two test groups (for AMP and ENR) and one control group.

\section{Conjugation of AMP and ENR with BSA}

AMP was conjugated with BSA as per the method described by Samsonova et al. [11] with slight modifications whereas ENR was conjugated by the method described by Sui et al. [12]. For conjugation $2.5 \mathrm{ml}$ of AMP $(100 \mathrm{mg} / \mathrm{ml})$ and $20 \mathrm{mg}$ of BSA were taken in a clean beaker and $2.5 \mathrm{ml}$ of ENR $(100 \mathrm{mg} / \mathrm{ml})$ and $20 \mathrm{mg}$ of BSA were taken in another clean beaker. $580 \mathrm{mg}$ of 1-ethyl-3-(3-dimethylaminopropyl) carbodiimide (EDC) was dissolved in $2 \mathrm{ml}$ of distilled water and was added drop-wise to each of the above mixtures separately, accompanied by continuous stirring on a magnetic stirrer. The $\mathrm{pH}$ of the solutions was adjusted to $5.0-6.0$ by adding $0.1 \mathrm{~N} \mathrm{HCl}$.

The above reaction mixtures of AMP-EDCBSA and ENR-EDC-BSA were incubated at room temperature (RT) in separate beakers with continuous stirring for $2 \mathrm{~h}$. After the reaction time of $2 \mathrm{~h}$, uncoupled antibiotic and EDC were removed by dialysis. Dialysis membrane having the cut-off molecular weight of 12-14 kDa was procured from Hi-Media (Cat.No.DM003). Dialysis was performed according to the method described by Bollag et al. [13]. The samples were dialyzed against phosphate buffer saline (PBS) ( $\mathrm{pH}-7.4)$ with four changes, each for $8 \mathrm{~h}$. The conjugated samples were analyzed by sodium dodecyl sulfate polyacrylamide gel electrophoresis (SDS-PAGE) to confirm successful conjugation [14]. SDS-PAGE was performed according to the method described by Christoph [14]. The images of the stained gels were taken in the gel documentation system (G-box-Syngene).

\section{Immunogen preparation}

For primary immunization, AMP and ENR immunogens were prepared by adding $40 \mu \mathrm{l}$ of each of the two conjugates separately to $460 \mu \mathrm{PBS}$ and $500 \mu 1$ of complete Freund's adjuvant. AMP and ENR booster immunogens were prepared by adding $40 \mu \mathrm{l}$ of the conjugate to $460 \mu \mathrm{l}$ of PBS buffer and $500 \mu 1$ of incomplete Freund's adjuvant as described by Dykman et al. [15].

The immunogen was mixed thoroughly, and $300 \mu \mathrm{l}$ was injected to each rat (test group) subcutaneously at two different sites $(150 \mu 1$ at each site $)$ according to the immunization schedule as described by Dykman et al. [15].

\section{Collection of blood from rats}

The blood was collected by orbital sinus venipuncture method described by Oruganti and Gaidhani [16]. A total of four blood collections were made in each group at different time intervals according to the schedule given in Table-1.

\section{Estimation of total protein, albumin, and A/G ratio}

The serum samples of rats from test and control groups collected after second booster (third immunization cycle $[\mathrm{IC}]$ ) were analyzed for total protein, albumin and $\mathrm{A} / \mathrm{G}$ ratio by using ensure biotech total protein and albumin teaching kit.

\section{Preparation of ELISA antigens (casein-antibiotic conjugates)}

$0.83 \mu \mathrm{mol}$ of casein was dissolved in $2 \mathrm{ml}$ of distilled water in the presence of small amount of sodium-bi-carbonate to maintain alkaline condition. $83 \mu \mathrm{mol}$ of antibiotic and $83 \mu \mathrm{mol}$ of EDC were added to the above protein solution. The reaction mixture was stirred on a magnetic stirrer continuously for $2 \mathrm{~h}$ at RT. The $\mathrm{pH}$ of the solution was adjusted to 5.0.

Table-1: Immunization schedule.

\begin{tabular}{ll}
\hline Immunization schedule & Procedure \\
\hline Day 0 & $1^{\text {st }}$ immunization antigen+CFA \\
Day 15 & $1^{\text {st }}$ boost antigen+ICFA \\
Day 30 & $1^{\text {st }}$ test bleed \\
Day 37 & $2^{\text {nd }}$ boost antigen+ICFA \\
Day 52 & $2^{\text {nd }}$ test bleed \\
Day 59 & $3^{\text {rd }}$ boost antigen+ICFA \\
Day 74 & $3^{\text {rd }}$ test bleed \\
Day 104 & $4^{\text {th }}$ test bleed
\end{tabular}

$\mathrm{CFA}=$ Complete Freund's adjuvant, ICFA=Incomplete Freund's adjuvant 
Reaction mixtures of both the antibiotics were then incubated overnight at $4^{\circ} \mathrm{C}$. Conjugates were dialyzed against distilled water as per the method given by Samsonova et al. [11].

\section{Standardization of icELISA}

The serum samples collected after the second booster (third IC) were used for the standardization. Checkerboard titration was performed using different dilutions of antigens against different serum dilutions of test groups and negative control at constant secondary antibody-horseradish peroxidase (HRP) conjugate dilution of $1 / 10,000$ (manufacturer's instruction). Serial antigen dilutions (from $2 \times 10^{6} \mathrm{ng} / \mathrm{ml}$ to $2 \mathrm{ng} / \mathrm{ml}$ ) were taken from rows $\mathrm{B}$ to $\mathrm{H}$ in 96 well polystyrene plates and serial primary antibody dilutions (from $1 / 50$ to $1 / 1600$ ) were taken from columns 1 to 6 for test group samples and columns 7 to 12 for control group samples. The dilution of antigen which showed, maximum absorbance reading and started to maintain almost a stationary phase was taken as the optimum according to the procedure described by Fan et al. [17].

\section{Indirect ELISA}

96 well flat bottom polystyrene ELISA plates (Nunc, Denmark) were coated with $250 \mu 1$ of antigen (antibiotic-casein conjugate) in $0.01 \mathrm{M}$ carbonate buffer $(\mathrm{pH}-9.6)$. The plates were incubated overnight at $4^{\circ} \mathrm{C}$. The wells were washed 3 times with $250 \mu \mathrm{l} /$ well of PBS that contained $0.05 \%$ tween 20 (PBST). The free (unbound) sites were blocked with $250 \mu \mathrm{l} /$ well of blocking buffer containing $2 \%$ casein. The plates were incubated at $37^{\circ} \mathrm{C}$ for $1 \mathrm{~h}$. The wells were washed 3 times with PBS, $250 \mu 1 /$ well. $100 \mu$ of antiserum samples with two-fold dilutions from $1 / 100$ to $1 / 6400$ in PBST were added to each well and the plate was incubated for $1 \mathrm{~h}$ at $37^{\circ} \mathrm{C}$. The wells were washed 3 times with PBST $(250 \mu \mathrm{l} /$ well per wash cycle). $100 \mu 1$ of a conjugate of secondary antibodies with HRP in PBST was added to each well and the plate was incubated for $1 \mathrm{~h}$ at $37^{\circ} \mathrm{C}$. The wells were washed 3 times with PBST $(250 \mu \mathrm{l} /$ well per wash cycle). $100 \mu 1$ of the substrate $(3,3$ ', 5, 5' tetramethylbenzidine) in PBST (1 in 20 dilution) was added to each well. The reaction was stopped after 10-15 min by adding $50 \mu \mathrm{l} /$ well of $4 \mathrm{M} \mathrm{H}_{2} \mathrm{SO}_{4}$ as the method described by Samsonova et al. [11]. Optical density (OD) was measured by using ELISA microtitre plate reader at $450 \mathrm{~nm}$ (Biotech instrument- $\mu$ quant).

\section{Testing the antiserum samples for antibody titres}

The antibody titres in the serum samples collected from immunized rats were tested by icELISA standardized as described above. The optimum antigen concentrations and primary antibody dilutions obtained for all the four antibiotics by the above-described method were used for the test. The antisera of all the three animals in each group collected during all the three ICs and $4^{\text {th }}$ sampling were tested at various serum dilutions ranging from $1 / 100$ to $1 / 1600$. Each sample was tested in duplicate including the control serum samples. In the reagent blank, PBST was added instead of antiserum. In the negative control wells, serum samples of control group rats were added. The mean $\mathrm{OD}_{450}$ of various serum dilutions at each IC for each group of rats were used to plot a graph with absorbance on Y-axis and serum dilutions on X-axis.

\section{Construction of PNT baseline}

The mean and the standard deviation (SD) values of the control group at each dilution ranging from $1 / 100$ to $1 / 6400$ were calculated for each of the two different antigen coated plates used in this study. Three units of SD was added to the corresponding mean absorbance value and a graph was plotted with values of mean plus 3 times SD $(M+3 S D)$ on Y-axis and serum dilutions on $\mathrm{X}$-axis. This was considered as positive, negative threshold (PNT) baseline [18]. Separate PNT baselines were constructed for each test group.

\section{Prediction of antibody titres}

The positive antibody titres were determined based on the cut-off value obtained from PNT baseline constructed. The highest $\mathrm{OD}_{450}$ value of the PNT baseline rounded off to the nearest single digit decimal was taken as cut-off value. The $\mathrm{OD}_{450}$ value over and above the cut-off value was considered positive antibody titer [18].

\section{Results and Discussion}

\section{Determination of successful conjugation}

Analysis of antibiotic conjugates by SDS-PAGE and coomassie blue staining revealed higher molecular weights of antibiotic-BSA conjugates when compared to normal BSA (Figure-1). Before conjugation with antibiotic, the molecular weight of BSA was $68 \mathrm{KDa}$. After conjugation, the molecular weights of conjugates were $85 \mathrm{kDa}, 74 \mathrm{kDa}$ for AMP-BSA and ENR-BSA, respectively. These results clearly indicate the successful conjugation of antibiotics with BSA and

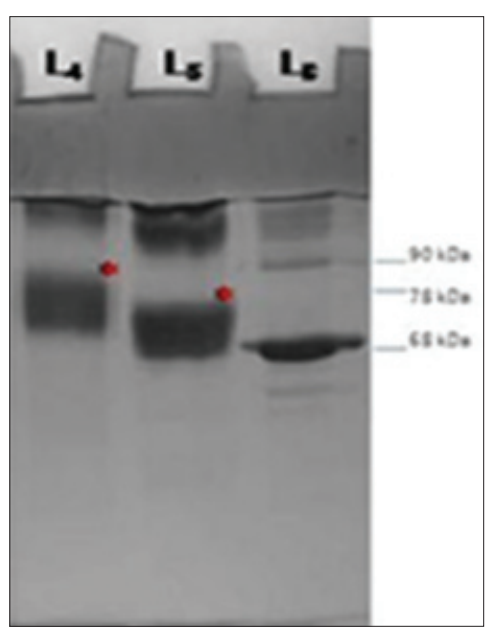

Figure-1: Coomassie blue stained sodium dodecyl sulfate polyacrylamide gel electrophoresis gel of antibiotic conjugates: $L_{4}$ : Ampillicin conjugate, $L_{5}$ : Enrofloxacin conjugate, $L_{6}$ : Bovine serum albumin $(*)$ conjugates. 
are similar to those obtained by Jiang et al. [19] who analyzed sarafloxacin-BSA conjugate by SDS-PAGE and observed an increase in the molecular weight of the conjugate when compared to the carrier protein BSA.

\section{Estimation of total protein, albumin and A/G ratio}

The mean values of total protein, albumin, globulin, and $\mathrm{A} / \mathrm{G}$ ratio of serum samples collected during third IC. The mean total protein concentration was $12 \pm 1.15 \mathrm{~g} / \mathrm{dL}$ and $24 \pm 1.73 \mathrm{~g} / \mathrm{dL}$ for AMP and ENR antisera, respectively and in the control group, it was $6.66 \pm 0.01 \mathrm{~g} / \mathrm{dL}$. The mean albumin concentration was $3.36 \pm 0.173 \mathrm{~g} / \mathrm{dL}, 3.21 \pm 0.003 \mathrm{~g} / \mathrm{dL}$ for AMP and ENR antisera are respectively compared to $3.36 \pm 0.173 \mathrm{~g} / \mathrm{dL}$ in the control group. The mean globulin concentration was $8.64 \pm 0.10 \mathrm{~g} / \mathrm{dL}$ and $20.79 \pm 0.08 \mathrm{~g} / \mathrm{dL}$ for AMP and ENR antisera, respectively, whereas it was $3.30 \pm 0.04 \mathrm{~g} / \mathrm{dL}$ in the control group. The mean $\mathrm{A} / \mathrm{G}$ ratio was $0.38 \pm 0.008$ and $0.15 \pm 0.017$ for $\mathrm{AMP}$ and ENR antisera, respectively. The mean $\mathrm{A} / \mathrm{G}$ ratio in the control group serum was $1.02 \pm 0.012$. Increased globulin concentration and decreased $\mathrm{A} / \mathrm{G}$ ratio indicates the presence of antibodies in the antisera.

\section{Standardization of antigen concentration and antise- rum dilution for indirect ELISA}

The checker board titration results are presented in Table-2 for AMP-casein conjugate and in Table-3 for ENR-casein conjugate. In all the titrations, the $\mathrm{OD}_{450}$ values of the test wells increased suddenly from the coated antigen concentration of 2 to $20 \mathrm{ng} / \mathrm{ml}$ and continued to maintain a steady phase at higher concentrations. So, $20 \mathrm{ng} / \mathrm{ml}$ was chosen as optimum antigen concentration. The absorbance values of the negative control wells dropped suddenly from serum dilution of $1 / 50$ to $1 / 100$ and continued to maintain similar range at higher dilutions and at all antigen concentrations. The test wells continued to maintain higher absorbance values at corresponding dilutions. Hence, 1/100 was chosen as optimum serum dilution. The highest $\mathrm{M}+3 \mathrm{SD}$ values obtained for negative sera were 0.213 (Table-4) and 0.209 (Table-5) for AMP-casein and ENR-casein coated plates, respectively. Hence, the cut-off value was selected as 0.3 for antibiotics.

\section{Detection of antibody titres in the AMP antisera}

The mean of the corrected OD values of the three animals in AMP test group and M + 3SD of the three animals in each control group at various serum dilutions and various ICs are depicted in Table-4. The highest $\mathrm{M}+3 \mathrm{SD}$ value was 0.213 . The cut-off value was selected as 0.3 (nearest single digit decimal above 0.213). The mean $\mathrm{OD}_{450}$ values of the serum samples from immunized rats were above the cut-off value up to serum dilution of $1 / 3200$ in all the three ICs and

Table-2: Checker board titration to standardize optimum casein-AMP conjugate and antiserum dilution.

\begin{tabular}{|c|c|c|c|c|c|c|c|c|c|c|c|c|c|}
\hline \multirow{4}{*}{$\begin{array}{l}\text { Concentration } \\
\text { of antigen } \\
(\mathrm{ng} / \mathrm{ml})\end{array}$} & \multirow{4}{*}{ Well } & \multicolumn{6}{|c|}{ Test serum sample } & \multicolumn{6}{|c|}{ Negative control } \\
\hline & & \multicolumn{6}{|c|}{ Dilutions of antisera } & \multicolumn{6}{|c|}{ Dilutions of antisera } \\
\hline & & $1 / 50$ & $1 / 100$ & $1 / 200$ & $1 / 400$ & $1 / 800$ & $1 / 1600$ & $1 / 50$ & $1 / 100$ & $1 / 200$ & $1 / 400$ & $1 / 800$ & $1 / 1600$ \\
\hline & & 1 & 2 & 3 & 4 & 5 & 6 & 7 & 8 & 9 & 10 & 11 & 12 \\
\hline Blank & $A$ & 0.148 & 0.159 & 0.078 & 0.190 & 0.111 & 0.178 & 0.091 & 0.163 & 0.143 & 0.155 & 0.140 & 0.147 \\
\hline $2 \times 10^{6}$ & B & 2.983 & 2.545 & 2.068 & 1.976 & 1.587 & 1.057 & 0.624 & 0.192 & 0.187 & 0.189 & 0.195 & 0.116 \\
\hline $2 \times 10^{5}$ & C & 2.745 & 2.451 & 1.987 & 1.852 & 1.456 & 0.958 & 0.525 & 0.112 & 0.185 & 0.165 & 0.159 & 0.112 \\
\hline $2 \times 10^{4}$ & D & 2.415 & 2.316 & 1.886 & 1.689 & 1.321 & 0.845 & 0.656 & 0.184 & 0.158 & 0.195 & 0.188 & 0.159 \\
\hline $2 \times 10^{3}$ & $E$ & 2.221 & 2.215 & 1.769 & 1.521 & 1.205 & 0.833 & 0.587 & 0.156 & 0.165 & 0.189 & 0.125 & 0.141 \\
\hline 200 & $\mathrm{~F}$ & 2.115 & 2.110 & 1.645 & 1.361 & 1.124 & 0.782 & 0.495 & 0.121 & 0.198 & 0.156 & 0.151 & 0.128 \\
\hline 20 & G & 2.021 & 1.994 & 1.607 & 1.246 & 0.972 & 0.759 & 0.458 & 0.184 & 0.185 & 0.136 & 0.102 & 0.196 \\
\hline 2 & $\mathrm{H}$ & 1.498 & 1.331 & 1.026 & 0.752 & 0.578 & 0.396 & 0.321 & 0.146 & 0.175 & 0.117 & 0.085 & 0.129 \\
\hline
\end{tabular}

$\mathrm{AMP}=$ Ampicillin

Table-3: Checker board titration to standardize optimum casein-ENR conjugate and antiserum dilution.

\begin{tabular}{|c|c|c|c|c|c|c|c|c|c|c|c|c|c|}
\hline \multirow{4}{*}{$\begin{array}{l}\text { Concentration } \\
\text { of antigen } \\
(\mathrm{ng} / \mathrm{ml})\end{array}$} & \multirow{4}{*}{ Well } & \multicolumn{6}{|c|}{ Test serum sample } & \multicolumn{6}{|c|}{ Negative control } \\
\hline & & \multicolumn{6}{|c|}{ Dilutions of antisera } & \multicolumn{6}{|c|}{ Dilutions of antisera } \\
\hline & & $1 / 50$ & $1 / 100$ & $1 / 200$ & $1 / 400$ & $1 / 800$ & $1 / 1600$ & $1 / 50$ & $1 / 100$ & $1 / 200$ & $1 / 400$ & $1 / 800$ & $1 / 1600$ \\
\hline & & 1 & 2 & 3 & 4 & 5 & 6 & 7 & 8 & 9 & 10 & 11 & 12 \\
\hline Blank & $A$ & 0.109 & 0.103 & 0.100 & 0.088 & 0.125 & 0.109 & 0.134 & 0.126 & 0.154 & 0.163 & 0.128 & 0.133 \\
\hline $2 \times 10^{6}$ & $\mathrm{~B}$ & 2.598 & 2.326 & 2.159 & 1.998 & 1.652 & 1.450 & 0.556 & 0.116 & 0.185 & 0.156 & 0.149 & 0.112 \\
\hline $2 \times 10^{5}$ & $\mathrm{C}$ & 2.441 & 2.236 & 2.079 & 1.789 & 1.536 & 1.241 & 0.531 & 0.121 & 0.186 & 0.152 & 0.145 & 0.198 \\
\hline $2 \times 10^{4}$ & D & 2.326 & 2.187 & 1.969 & 1.656 & 1.324 & 1.105 & 0.401 & 0.178 & 0.156 & 0.123 & 0.189 & 0.119 \\
\hline $2 \times 10^{3}$ & $\mathrm{E}$ & 2.158 & 2.056 & 1.851 & 1.523 & 1.121 & 0.959 & 0.459 & 0.189 & 0.187 & 0.125 & 0.197 & 0.157 \\
\hline 200 & $\mathrm{~F}$ & 2.103 & 1.925 & 1.754 & 1.386 & 0.956 & 0.843 & 0.358 & 0.142 & 0.195 & 0.178 & 0.185 & 0.139 \\
\hline 20 & G & 2.044 & 1.889 & 1.595 & 1.027 & 0.819 & 0.775 & 0.338 & 0.196 & 0.183 & 0.138 & 0.118 & 0.141 \\
\hline 2 & $\mathrm{H}$ & 1.156 & 0.721 & 0.521 & 0.495 & 0.352 & 0.229 & 0.352 & 0.185 & 0.189 & 0.119 & 0.158 & 0.176 \\
\hline
\end{tabular}

ENR $=$ Enrofloxacin 
Table-4: Mean $\mathrm{OD}_{450}$ values of indirect ELISA of AMP antisera.

\begin{tabular}{lccccccc}
\hline ICs & \multicolumn{7}{c}{ Serum dilutions } \\
\cline { 2 - 7 } & $\mathbf{1 / 1 0 0}$ & $\mathbf{1 / 2 0 0}$ & $\mathbf{1 / 4 0 0}$ & $\mathbf{1 / 8 0 0}$ & $\mathbf{1 / 1 6 0 0}$ & $\mathbf{1 / 3 2 0 0}$ & $\mathbf{1 / 6 4 0 0}$ \\
\hline $1^{\text {st }}$ IC & 1.499 & 1.156 & 0.840 & $\mathbf{0 . 6 6 8}$ & 0.458 & 0.323 & 0.281 \\
$2^{\text {nd }}$ IC & 1.781 & 1.607 & 1.429 & 1.225 & $\mathbf{0 . 9 2 4}$ & 0.568 & 0.436 \\
$3^{\text {rd }}$ IC & 2.577 & 2.195 & 1.841 & 1.619 & 1.453 & 1.417 & $\mathbf{1 . 1 8 4}$ \\
$4^{\text {th }}$ collection & 1.944 & 1.601 & 1.267 & $\mathbf{0 . 9 3 2}$ & 0.756 & 0.642 & 0.558 \\
Negative control (M+3SD) & 0.213 & 0.199 & 0.157 & 0.12 & 0.107 & 0.105 & 0.107 \\
\hline
\end{tabular}

Bold numbers indicate $50 \%$ titres. IC=Immunization cycle, OD=Optical density, ELISA=Enzyme linked immunosorbent assay, $\mathrm{AMP}=$ Ampicillin

Table-5: Mean $\mathrm{OD}_{450}$ values of indirect ELISA of ENR antisera.

\begin{tabular}{lccccccc}
\hline IC & \multicolumn{7}{c}{ Serum dilutions } \\
\cline { 2 - 8 } & $\mathbf{1 / 1 0 0}$ & $\mathbf{1 / 2 0 0}$ & $\mathbf{1 / 4 0 0}$ & $\mathbf{1 / 8 0 0}$ & $\mathbf{1 / 1 6 0 0}$ & $\mathbf{1 / 3 2 0 0}$ & $\mathbf{1 / 6 4 0 0}$ \\
\hline $1^{\text {st }}$ IC & 1.018 & 0.735 & $\mathbf{0 . 4 4 7}$ & 0.297 & 0.148 & 0.099 & 0.065 \\
$2^{\text {nd }}$ IC & 1.252 & 1.046 & 0.759 & $\mathbf{0 . 6 2 8}$ & 0.445 & 0.302 & 0.272 \\
$3^{\text {rd }}$ IC & 1.723 & 1.476 & 1.241 & 1.091 & 0.94 & $\mathbf{0 . 8 9 3}$ & 0.755 \\
$4^{\text {th }}$ Sampling & 1.04 & 0.783 & $\mathbf{0 . 5 6 5}$ & 0.461 & 0.399 & 0.275 & 0.191 \\
Negative control (M+3SD) & 0.209 & 0.216 & 0.158 & 0.16 & 0.115 & 0.105 & 0.099 \\
\hline
\end{tabular}

Bold numbers indicate $50 \%$ titres. IC=Immunization cycle, OD=Optical density, ELISA=Enzyme linked immunosorbent assay, ENR=Enrofloxacin, SD=Standard deviation

fourth collection which indicated positive antibody titers (Figure-2). The values of $50 \%$ antibody titres increased from the antiserum dilution of $1 / 800$ in first IC to $1 / 6400$ in third IC as depicted in Table-4. The AMP antisera gave positive antibody titers up to a dilution of 1/3200 in first IC and 1/6400 in second and third ICs and fourth sampling. Maximum $\mathrm{OD}_{450}$ value of 2.577 was obtained at $1 / 100$ antiserum dilution in third IC which clearly indicated that the immune response was the highest in third IC. The immune response significantly increased from first IC to third IC at 1/100 antiserum dilution and decreased in fourth collection (Figure-3). Anti-AMP antibodies were successfully produced by Strasser et al. [20] in rabbits which were confirmed by double antibody solid phase ELISA. The maximum antibody titer of 1:550,000 was obtained after third booster injection (fourth IC) at working antiserum dilution of 1:1000 which is much higher than $1 / 6400$ in this study. The difference could be attributed to species variations in the ability to produce antibodies. Competitive ELISA used by McConnell et al. [21] for AMP antisera yielded positive antibody titers indicating clearly that AMP-carrier protein conjugate was immunopotent and capable of eliciting specific immune response.

\section{Detection of antibody titres in the ENR antisera}

The results of corrected mean $\mathrm{OD}_{450}$ values of the test group (three animals) and $\mathrm{M}+3 \mathrm{SD}$ values of the control group (three animals) at various serum dilutions and various ICs are depicted in Table-5. The highest $\mathrm{M}+3 \mathrm{SD}$ value was 0.209 . The cut-off value was selected as 0.3 (nearest single digit decimal above 0.209). The mean $\mathrm{OD}_{450}$ values of the ENR antisera were above the cut-off value up to a dilution of $1 / 400$ in first IC and up to dilution of 1/1600 in second and third and ICs and fourtth collection which indicated

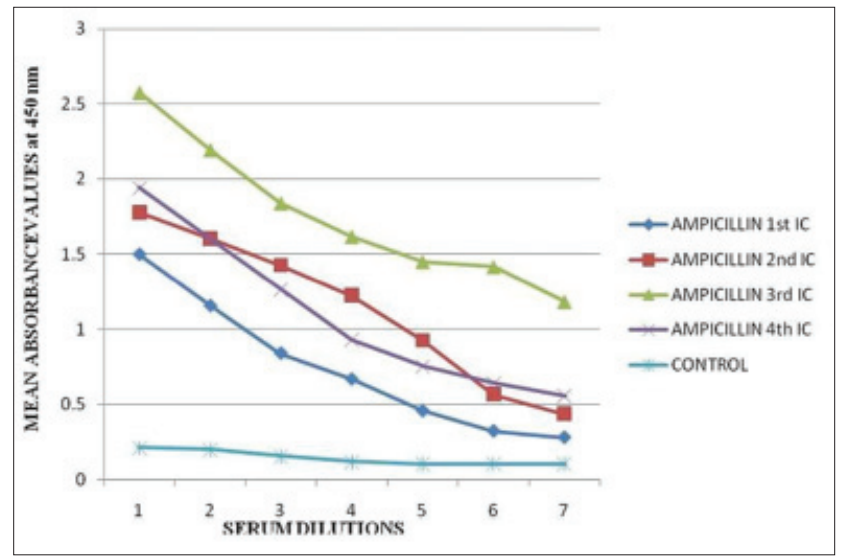

Figure-2: Calibration curve for indirect enzyme linked immunosorbent assay of bovine serum albumin-ampicillin antisera at various immunization cycles $(1,2,3,4,5,6,7$ represents serum dilutions of $1 / 100,1 / 200,1 / 400,4 / 800$, $1 / 1600,1 / 3200$, and $1 / 6400$ respectively).

positive antibody titres (Figure-4). The immune response significantly increased from first IC to third IC at 1/100 antiserum dilution and decreased in fourth sampling (Figure-5). The values of $50 \%$ antibody titres increased from the antiserum dilution of $1 / 400$ in first IC to $1 / 3200$ in third IC as depicted in Table-5. The ENR antisera gave positive antibody titres up to a dilution of $1 / 400$ in first IC, $1 / 3200$ in second IC, $1 / 6400$ in third IC and $1 / 1600$ in fourth sampling. Maximum $\mathrm{OD}_{450}$ value of 1.723 was obtained at $1 / 100$ antiserum dilution in third IC which clearly indicated that the immune response was the highest in third IC. Liu et al. [22] used ELISA and competitive inhibition ELISA to determine antibody titers in ENR antisera and obtained antibody titre as high as 1:250,000 for three analogs of ENR belonging to fluoroquinolone family. 


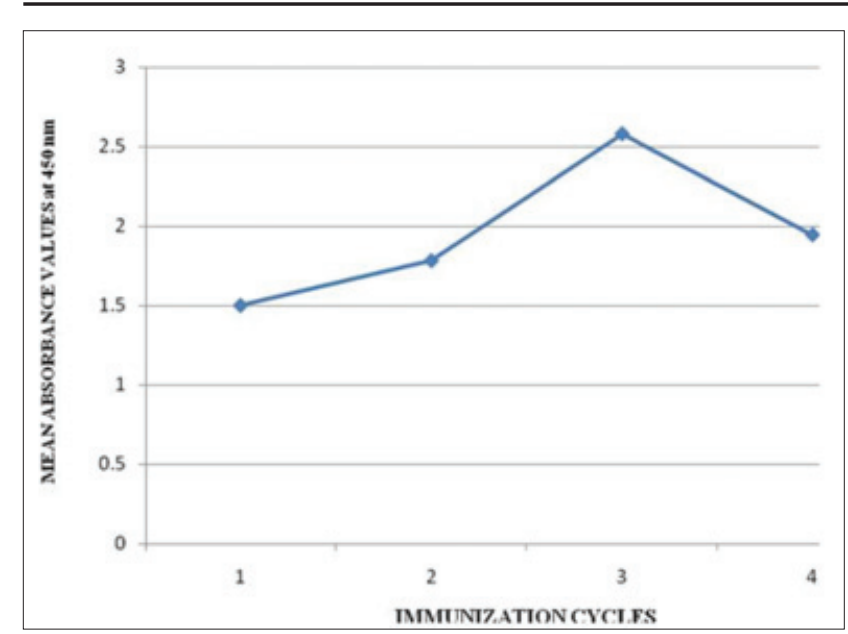

Figure-3: Calibration curve for indirect enzyme linked immunosorbent assay of bovine serum albumin-ampicillin antisera at $1 / 100^{\text {th }}$ serum dilution of various immunization cycles (ICs) $\left(1,2,3,4\right.$ represents serum dilutions of $1^{\text {st }}$, $2^{\text {nd }}, 3^{\text {rd }}, 4^{\text {th }}$ ICs respectively at $1 / 100^{\text {th }}$ serum dilation).

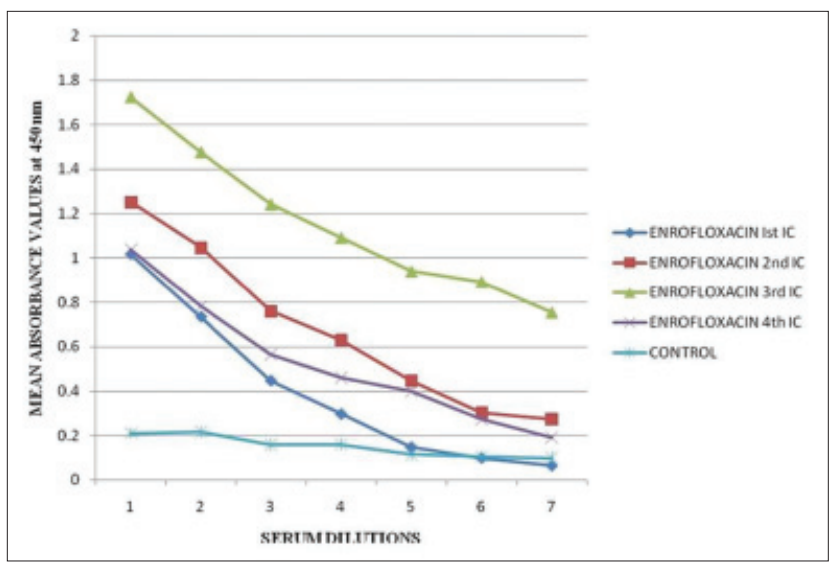

Figure-4: Calibration curve for indirect enzyme linked immunosorbent assay of bovine serum albuminenrofloxacin antisera at various immunization cycles (1, 2, $3,4,5,6,7$ represents serum dilutions of $1 / 100,1 / 200$, $1 / 400,4 / 800,1 / 1600,1 / 3200$, and $1 / 6400$ respectively).

\section{Comparative immunogenic potency of AMP-BSA and ENR-BSA antisera}

Highest immune response was seen in AMP antiserum followed by ENR evidenced by $\mathrm{OD}_{450}$ values of 2.577, 1.723 for AMP and ENR antisera respectively at $1 / 100$ serum dilution in third IC (Figure-6).

\section{Raised antibodies to detect the AMP and ENR in milk samples}

To use produces antibodies for the detection of antibiotics in milk samples, we need large quantities of antibodies for which the work has to be scaled up and large number of animals have to be maintained to obtain sufficient antiserum for harvesting antibodies. This is the first part of work done to test the efficacy of BSA conjugates of AMP and ENR in eliciting immune response in rats. The second part of work is to scale up the process and use the antibodies in developing quantitative assay or lateral flow through assay to detect antibiotic residues in milk samples.

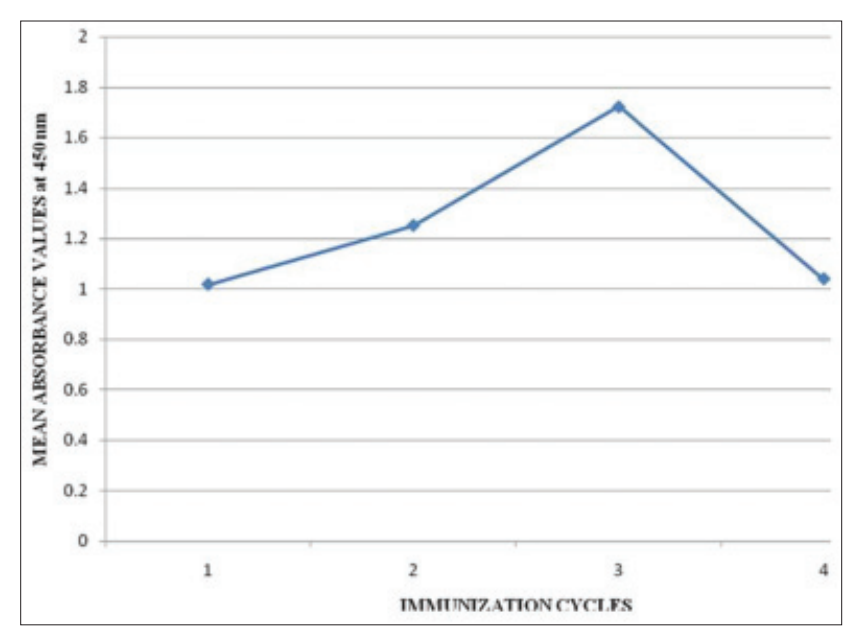

Figure-5: Calibration curve for indirect enzyme linked immunosorbent assay of bovine serum albumin-enrofloxacin antisera at $1 / 100^{\text {th }}$ serum dilution of various immunization cycles (IC) $\left(1,2,3,4\right.$ represents serum dilutions of $1^{\text {st }}, 2^{\text {nd }}$, $3^{\text {rd }}, 4^{\text {th }}$ ICs respectively at $1 / 100^{\text {th }}$ serum dilation).

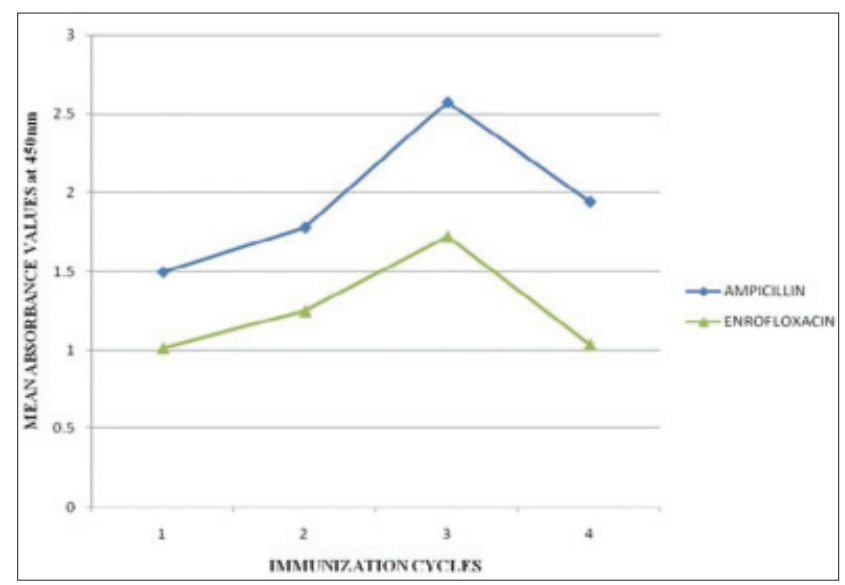

Figure-6: Comparative calibration curves for indirect enzyme linked immunosorbent assay of bovine serum albumin-antibiotic antisera at $1 / 100^{\text {th }}$ serum dilution of various immunization cycles (ICs) $(1,2,3,4$ represents serum dilutions of $1^{\text {st }}, 2^{\text {nd }}, 3^{\text {rd }}, 4^{\text {th }}$ ICs respectively at $1 / 100^{\text {th }}$ serum dilation).

\section{Novelty and contribution to the animal health}

This work mostly concerned with the public health importance. Antibiotics residues in milk higher than maximum residue levels are of great concern to dairy farmers, milk processors, regulatory agencies, and consumers due to their possible adverse effects on people allergic to antibiotics, potential buildup of antibiotic-resistant organisms in humans [23]. The novelty of this work lies in using BSA as a suitable conjugating agent with EDC as coupler for AMP and ENR which are otherwise haptens and hence incapable of eliciting immune response.

\section{Conclusion}

In this study, the antibiotics (AMP and ENR) were successfully conjugated with carrier protein BSA by carbodiimide reaction using EDC as a cross linker. These conjugated antibiotics were capable of producing pAbs which was confirmed by indirect ELISA. 


\section{Authors' Contributions}

BSK and PK collected the blood samples from rats for the study. BSK carried out the current investigation under the guidance of VA. BSK drafted and revised the manuscript under the guidance of PK. GRN helped in carry out the ELISA part of work. All the authors have read and approved the manuscript.

\section{Acknowledgments}

The authors gratefully acknowledge Sri Venkateswara Veterinary University, Tirupati for providing facilities and funds to do research work as part of the M.V.Sc. thesis work.

\section{Competing Interests} interests.

The authors declare that they have no competing

\section{References}

1. Singh, S., Shukla, S., Tandia, N., Kumar, N. and Paliwal, R. (2014) Antibiotic residues: A global challenge. Pharm. Sci. Monitor, 5(3): 184-197.

2. Fitzgerald, S.P., Loan, N., Connell, R.M., Benchi, E.KH. and Kane, N. (2007) stable competitive Enzyme-Linked immunosorbent assay kit for rapid measurement of 11 active beta-lactams in milk, tissue, urine and serum. J.AOAC. Int., 90 (1):334-342.

3. Kebede, G., Zenebe, T., Disassa, H. and Tolosa, T. (2014) Review on detection of antimicrobial residues in raw bulk milk in dairy farms. AJBAS., 6(4): 87-97.

4. Padol, A.R., Malapure, C.D., Domple, V.D. and Kamdi, B.P. (2015) Occurance, public health implications and detection of antibacterial drug residues in cow milk. Environ. We Int. J. Sci. Tech., 10: 7-28.

5. Yan, H., Wang, H., Qin, X., Liu, B. and Du, J. (2011) Ultra sound-assisted dispersive liquid-liquid micro extraction for determination of fluroquinolones in pharmaceutical waste water. J. Pharm. Biomed. Anal., 54(1): 53-57.

6. Dinki, N. and Balcha, E. (2013) Detection of antibiotic residues and determination of microbial quality of raw milk from milk collection centres. Adv. Anim. Vet. Sci., 1(3): 80-83.

7. Zeina, K., Pamela, A.K. and Fawwak, S. (2013) Quantification of antibiotic residues and determination of antimicrobial resistance profiles of microorganisms isolated from bovine milk in Lebanon. Food Nutr. Sci., 4: 1-9.

8. Dhakal, I.P., Dhakal, P., Koshihara, T. and Nagahata, H. (2007) Epidemiological and bacteriological survey of buffalo mastitis in Nepal. J. Vet. Med. Sci., 69(12): 1241-1245.
9. Suzanne, N.S. and Lioyd, E.M. (2003) In: Food Analysis. Kluwer Academic/Plenum Publishers, New York. p35-49.

10. Lipman, N.S., Jackson, L.R., Trudel, L.J. and WeisGarcia, F. (2005) Monoclonal versus polyclonal antibodies: Distinguishing characteristics, applications, and information resources. ILAR J., 46(3): 258-268.

11. Samsonova, Z.V., Shchelokova, O.S., Ivanova, N.L., Rubtsova, M.Y. and Egorov, A.M. (2005) Enzyme-linked immunosorbent assay of ampicillin in milk. J. Appl. Biochem. Microbiol., 41: 589-595.

12. Sui, J., Hong, L., Limin, C. and Zhenxing, L. (2009) Dotimmunogold filtration assay for rapid screening of three fluroquinolones. J. Food Agric. Immunol., 20: 125-137.

13. Bollag, D., Micheal, D.R. and Stuart, J.E. (1996) In: Protein Methods. $2^{\text {nd }}$ ed. Ch. 3, 4, 5. Wiley-Liss Publication, USA. p68, 86, 91, 103, 108 .

14. Christoph, K. (2002) Posttranslational modifications of proteins: tools for proteomics. In: methods in molecular biologypp.

15. Dykman, L.A., Sumaroka, M.V., Staroverou, S.A., Zaltseva, I.S. and Bogatyrev, V.A. (2004) Immunogenic properties of colloidal gold. Biol. Bull., 31: 75-79.

16. Oruganti, M. and Gaidhani, S. (2011) Routine bleeding techniques in laboratory rodents. IJPSR., 2(3): 516-524.

17. Fan, G.Y., Yang, R.S., Jiang, J.Q., Chang, X.Y., Chen, J.J., Qi, Y.H., Wu, S.X. and Yang, X.F. (2012) Development of a class-specific polyclonal antibody based indirect competitive ELISA for detecting fluoroquinolone residues in milk. J. Zhejiang Univ. Sci. B. 13(7): 545-554.

18. Ramadass,P., Parthiban, M., Thiagarajan, V., Chandrasekar, M., Vidhya, M. and Raj, G.D. (2008) Development of single serum dilution ELISA for detection of infectious bursal disease virus antibodies. J. Vet. Arch., 78: 23-30.

19. Jiang, J., Zhang, H. and Wang, Z. (2011) Development of an immunoassay for determination of fluroquinolones pollutant in environmental water sample. International conference on nanotechnology and biosensors. IPCBEE., 2: 1-4.

20. Strasser, A., Usleber, E., Schneider, E., Dietrich, R., Burk, C. and Martlbauer, E. (2003) Improved enzyme immune assay for group-specific determination of penicillins in milk. J. Food Agric. Immunol., 15: 135-143.

21. McConnell, R.I., Elouard, B., Stephen, P.F. and John, V.L. (2003) Method and kit for detecting, or determining the quantity of beta-lactam penicillins. United States Patent, Patent No. US 6960653 B2.

22. Liu, C., Hong, L., Limin, C. and Jie, J. (2005) Anti-ENR antibody production by using ENR-screened HSA as an immunogen. J. Ocean U China, 4(3): 262-266.

23. Tiwari, R., Chakraborty, S., Dharma, K., Rajagunalan, S. and Singh, S.V. (2013) Antibiotic resistance - An emerging health problem: Causes, worries, challenges and solutions A review. Int. J. Curr. Res., 5(7): 1880-1892. 